\title{
Asymmetric Effects of Capital Flight on Domestic Investment in Nigeria: Evidence from Non-Linear Autoregressive Distributed Lag Model
}

LIONEL EFFIOM ( $\sim$ leoeff2002@yahoo.com )

University of Calabar https://orcid.org/0000-0002-1000-836X

EMMANUEL UCHE

Abia State University

OTEI ASUQUO OTEI

University of Calabar

FRANCIS ARCHIBONG EFFIONG

University of Calabar

\section{Research}

Keywords: Asymmetric Effect, Capital Flight, Domestic Investment, Nonlinear Autoregressive Distributed Lag Model, Nigeria, JEL Classification: E 22, F32

Posted Date: November 25th, 2020

DOl: https://doi.org/10.21203/rs.3.rs-113386/v1

License: (9) This work is licensed under a Creative Commons Attribution 4.0 International License. Read Full License 


\title{
Asymmetric Effects of Capital Flight on Domestic Investment in Nigeria: Evidence from Non-Linear Autoregressive Distributed Lag Model
}

\author{
Lionel Effiom ${ }^{1}$ \\ Department of Economics \\ University of Calabar \\ Calabar, Cross River State, Nigeria \\ leoeff2002@yahoo.com \\ (Corresponding Author) \\ Uche, Emmanuel \\ Department of Economics, \\ Abia State University, Uturu \\ Abia State, Nigeria \\ uche.emmanuel@abiastateuniversity.edu.ng \\ Otei Asuquo Otei \\ Department of Economics \\ University of Calabar \\ Calabar, Cross River State, Nigeria \\ otei.otei@yahoo.com \\ And \\ Francis Archibong Effiong \\ Department of Economics \\ University of Calabar \\ Calabar, Cross River State, Nigeria \\ jefa4real@yahoo.com
}

${ }^{1}$ Corresponding Author 


\section{Introduction}

Classical economic theory underlines the pivotal role of investment in accelerating the pace of economic growth. Investment could be conceptualised as either in the direction of human capital or physical capital. It could also be viewed in terms of its source: in an autarky, aggregate investment is seen largely as emanating from only within the domestic economy, while in an open economy, it could be driven by the inflow of capital, either as foreign direct investment or as foreign portfolio investment. Thus, economic policy must ensure that the economy witnesses and benefits from large doses of investment, whether domestically-driven or by way of FDI. In other words, there has to be significant positive change in the capital stock to ensure growth. Furthermore, policy must evolve ways of making investment more productive by way of enhancing the efficiency of productive factors in the aggregate input-mix, and also ensure that efforts at domestic mobilization of investment is not compromised by capital flight. But developing economies, including Nigeria, are not so blessed with positive doses of these phenomena. While domestic capacity for investments is largely constrained by structural challenges ranging from the economic, to the social, and even political, it is also made worse by the blighting effects of flight capital.

There is a recurring and frightening amount of capital exiting the Nigerian economy in recent times compared to aggregate domestic investment, leading to a reduction of potential growth. For instance, estimates of flight capital in Nigeria in 2010 exceeded \$311million, approximating 158.2\% capital flight-GDP ratio. The proportion of real GDP lost to capital flight in Nigeria stood at $4.7 \%$ (Effiom and Edet, 2019). From 2012 to 2015, the rate of growth of Nigeria's capital flight has been decreasing, though it is still significantly huge when considered in absolute values (Englama, et al. 2007). Deppler and Williamson (1987) noted that the growth rate of the domestic economy is constrained by an amount basically equivalent to the magnitude of capital flight. Capital flight reduces the investible capital available in the domestic economy (Ndikumana and Boyce 2018). This submission is corroborated by The World Bank (2015) which notes that in 1990, Nigeria's domestic investment stood at $\$ 43.8$ billion, which dropped consecutively for two periods - $\$ 37.3 \mathrm{bn}$ in 1992 to \$20.1bn in 1995. However, from 2010 to 2015, there was a significant capital outflow exceeding $\$ 900 \mathrm{bn}$ compared to a paltry domestic investment of $\$ 134 \mathrm{bn}$. Updated estimates reveal that capital flight stood at $\$ 411.0$ in 2015, representing capital flight-GDP ratio of $68.8 \%$ (Ndikumana and Boyce, 2018).

Several streams of research have been devoted to investigating the growth impact of capital flight in Nigeria (see for instance Umoru 2013; Onwioduokit, 2000; Samson and Edeme, 2012; (Ajayi, 1997, etc). However, only a single study (i.e. Adetiloye, 2012) focuses specifically on domestic investment impact of capital flight. Even then, that study is fundamentally flawed because 
the capital flight variable is clearly lacking as an explanatory variable in the empirical model. The current paper, besides adding to the already rich body of empirical studies on capital flight in Nigeria, is significant on two scores. First, the study takes a comprehensive and disaggregated view of domestic investment in Nigeria. Previous studies focused on investment at the Federal or Central Government, without a corresponding emphasis on that undertaken by subnational units. It must be noted that Nigeria's federal political structure consist of a three-tier administrative system with concurrent albeit unequal spending powers, with the central and state governments having considerable influence on domestic investment dynamics.

Secondly, studies on the effect of capital flight on growth or on different sectors of the economy generally assume an underlying linear relationship. These studies are premised on the assumption that the impact of capital flight on investment is symmetric, meaning that reductions in capital flight should equally lead to proportionate increases in investment levels. This might not be so given the mobility and speed in which capital travels internationally with the aid of financial innovation platforms (Lerner and Tufano, 2011), coupled with the negative indirect impact capital flight might have on other macroeconomic variables directly associated with investments, such as exchange rate and inflation. Thus, this paper contributes to the capital flight literature in Nigeria by decomposing changes in capital flight into their partial sum of negative and positive changes and investigates if these variations have asymmetric impacts on investment. In contrast to the linear form of the autoregressive distributed lag (ARDL) framework, the paper employs the nonlinear ARDL (NARDL) developed by Shin et al. (2014) which permits the separate estimation of the effect of capital flight increases and capital flight decreases on domestic investment levels. A major research question is: is there a tendency for domestic investment to maintain a downward spiral or a ratchet effect, even in the face of lower levels of capital flight? Employing the NARDL, the study finds evidence of asymmetric impact of capital flight on aggregate investment in Nigeria. This is arguably the first attempt in the capital flight literature in Nigeria. The findings of the study have implications for policy, namely, that policy makers might be misled to assuming that periods of decline in capital flight might necessarily translate to the availability of more financial resources for investment purposes. The reality might be that the damaging effects of capital flight on the domestic economy through its influence on macroeconomic indicators of exchange rate, interest rate and inflation might persist into periods of capital flight decline, thus frustrating the investment capacity of the government. The remainder of the paper is devoted to finding answers to this enquiry.

\section{Literature Review}

\subsection{Theoretical Linkage between domestic investment and capital flight}


The underlying notion of capital flight is that it is a transfer of domestic resources, whether they are of the public or private sources. From the domestic private investment angle, capital flight leads to a reduction in savings, with banks mobilising less savings deposits. With lower levels of savings mobilisation, there is an increasing constraint on the banking sector's capacity to extend credit. This ultimately results in lower levels of domestic investment itself. As noted by Ajayi, (1997), the tax base is also adversely affected by capital flight, leading to diminishing government revenue. This negatively leads to a reduction in public investment, with negative consequences on private investment. A further corollary of this negative process is that continuous reduction in public revenue due to the erosion of the tax base via capital flight may lead to an increase of seignorage by the government. This will inevitably lead to an increase in inflation tax, which may compel investors to divest in the domestic economy, so as to escape the devaluation of the real worth of their assets occasioned by the inflation tax surge. Thus, in line with the prediction of the portfolio selection theory, they may be induced to seek investment opportunities elsewhere (Collier et al. 2004).

Equally important is the fact that increased capital flight can propel uncertainty and doubts on the part of agents in the capacity of the government to finance its deficit budgets or debt. Thus, persistent fiscal deficits put pressure on the financing needs of the government. This leads to inflationary tensions, thus, increasing the tendency for the depletion of domestic assets held by the private sector. This results in a decrease in private investment, if this occurs. From a different perspective, persistent budget deficits may result in debt unsustainability. Ndiaye (2014) observes that in relation to domestic debt, debt unsustainability may lead to a risk of bankruptcy of private firms, leading ultimately to reduction in private domestic investment. On the other hand, rising and unsustainable government debt may lead to lack of confidence in government securities. Financial markets may respond poorly when government bonds are issued. A third consequence of rising debt is that investors may be forced to anticipate tax increases by the government to deal with the situation. This increases the risk of a decline in the value of domestically-acquired assets and may compel private domestic agents to alter their portfolio of assets in favour of foreign denominated assets.

There is also the issue of speculative bubbles in relation to the effect of capital flight on domestic investment. With capital flight comes diminishing control over outflows of capital. However, unregulated capital flow exacerbates the volatility which results in uncertainty in the macroeconomic environment, resulting in a potential loss of private sector assets. Consequently, domestic private investors may seek for safe havens outside of the domestic environment.

Several approaches have been deployed in measuring capital flight, namely, balance of payment, residual, and bank deposit approaches. In this study, the residual approach of the World 
Bank (1985) is used, being the most extensively employed method of measuring capital flight because it obviates the distinction of capital flight from normal capital outflows (World Bank, 1985)

\subsection{Empirical literature}

The capital flight literature has a rich historical antecedent, partly because the phenomenon has lived and lingered for long - not only in Nigeria but in sub-Sahara Africa and other developing countries. It does appear however that it is worse in the former than in other continents (Collier et al. 2001; Henry, 2012). These studies show that relative to other regions, Africa has low levels of capital stock. However, African nationals have a tendency to hold a greater proportion of their investments overseas compared to nationals of other regions.

Trevelline (1999) notes several factors responsible for the birth, growth and sustenance of capital flight globally. Among these are the ready availability of efficient and safe medium of funds transfer across national boundaries; developments in information and communications technology (ICT), as well as efficiency in different modes of transportation which aid in keeping track of investments overseas. Others are the rate at which information and knowledge about global financial centres like London and New York are disseminated; the widespread and universal use of the United States dollar which obviates the need to convert local currencies to the dollar because most developing countries already hold their liquid assets in the dollar or other global convertible currencies. Tornell and Velasco (1992) also observe that the institutionalization of capitalism as the dominant economic system worldwide, as well as the evolution of welfarism to ameliorate the crushing effect of capitalism, has made private investors to seek safe havens abroad to avoid taxation by the state.

These avenues through which capital exits a country's economy, combined with unhealthy domestic macroeconomic and political conditions, results in massive and widespread distortions and loss of confidence by private capital holders. On the macro front, high and persistent inflation, cost of capital differentials, differentials in the rate of return on investment, huge budget deficits, exchange rate devaluation, poor governance, as well as domestic tax cum trade policies may significantly inspire the flight of capital from the domestic economy (Asongu \& Nnanna, 2020; Asongu \& Odhiambo, 2019; Gankou et al.2016; Ndikumana, 2016; Okoli \& Akujuobi, 2009; Hermes \& Lensink, 2000; Cuddington, 1987; Lessard and Williamson, 1987; Olopoenia, 2000).

Other studies identify low GDP growth rates (Anetor, 2019; Pastor, 1990; Nyoni, 2000), rising inflow of foreign aid (Aziz et. al. 2014; Collier, Hoeffler, and Pattillo, 2004), as well as external debt overhang (Al-Basheer et. al. 2016; Chipalkatti and Rishi, 2001; Demir, 2004). Non-economic or political factors including political instability, insecurity, leakages in public financial management ( Forson, Obeng and Brafu-Insaidoo,2017;World Bank, 2015; Le and Rishi, 2005), for instance, may 
conspire with the above factors to encourage flight capital out of the domestic economy. In particular, Ndikumana (2014) submits that the existence and proliferation of safe or tax havens facilitates capital flight in sub-Saharan African countries. These mechanisms aid to conceal and transfer illicit capital procured through embezzlement, over invoicing of imports and under-invoicing of exports, corruption, tax evasion and sheer and brazen smuggling of natural resources and capital out of the domestic economy.

The revelations contained in the Panama Papers suggest that capital flight from Africa and other developing countries are far from abating; indeed, it is increasing in an overwhelming scale. As early as the 1990s studies indicated massive amounts of capital flight transferred abroad (see for instance Chang and Cumby, 1991; Ajayi and Khan, 2000; Hermes and Lensink, 2000). With regards to Nigeria, there seems to be no precise estimate of capital flight from the country due to general methodological differences and a lack of consensus on measurement parameters in the literature. However, a study conducted by Le and Zak (2006) estimates that capital flight for Nigeria in 1987 was $31.0 \%$ of GDP, while Collier et al. (2001) reveal that as at 1999 Nigeria's capital flight was \$107billion as against \$51.8billion aggregate real GDP for the same year. Using several measures, Englama et. al. (2007) estimated the capital flight for Nigeria from 1971 to 2006. With the World Bank (1985), they found a capital flight of \$16.14billion, with Morgan Trust co. measure of 1986, capital flight was $\$ 64$.26billion, while it found a capital flight of \$130.80billion when it deployed the Modified Approach. In particular, CBN (2015) reveals that the net capital flows for Nigeria was in the sum of $\$ 8.8$ trillion and $\$ 1.1$ trillion in 2011 and 1999, while the IMF (2015) reports a whopping $\$ 11.6$ trillion held as offshore assets and $\$ 866$ billion as income generated by these assets accruing to other countries. Consequently, countries steeped in capital flight loose tax revenues amounting to about $\$ 255$ billion.

While studies devote attention to the investigation of the effect of capital flight on the Nigerian economy generally using GDP as proxy, there are several studies though, which investigate the sectoral impact of capital flight. For example, the impact of capital flight on the agricultural sector in Nigeria was investigated by Usman and Arene (2014). The study found an insignificant but negative impact of capital flight on the sector. Similarly, Uguru (2016) find evidence of an inverse relationship between capital flight and tax revenues in Nigeria. A study that is very relevant to our current investigation is that of Rahmon (2017) who examined the impact of capital flight on domestic investment in Nigeria. An interesting result emanated from this study, namely "that capital flight has a statistically significant positive relationship with gross domestic investment in Nigeria contrary to a priori theoretical expectation". The rational implication of this is that as capital flight increases, domestic investment increases. This is indeed curious. However, the policy recommendation of the 
paper is inconsistent with the findings, when it recommends that "government should intensify its efforts to ensure speedy recovery of looted funds by corrupt public office holders from foreign accounts to inject funds into the economy for investment purposes". One would have thought that with a positive relationship found between capital flight and domestic investment, the rational policy outcome should have been an encouragement of capital flight.

Thus given this theoretical inconsistency as well as the realization that to the best of our knowledge no study is yet to be conducted to ascertain the asymmetric relationship or effects of flight capital on Nigeria's domestic investment, the present study undertakes to fill this gap. Our operationalization of domestic investment excludes private sector investment for, as argued above, much of capital flight in Nigeria is directed against public resources.

\subsection{Stylised facts of capital flight and domestic investment in Nigeria}

The Nigerian economy has witnessed massive outflow of capital (mostly dollar denominated) as politicians, corporate bodies and foreign investors move funds out of the country in response to insecurity, macroeconomic instability as well as exchange and interest rates differential. Table 1 and the accompanying figure 1 show that the magnitude of capital flight is alarming. From $\$ 3387$ billion in 1980, capital flight rose abruptly to \$10728billion in 1981 and plummeted the following year, rising acutely again to $\$ 11569.3$ in 1983 . It should be noted that this period of undulating trends in capital flight coincided with pervasive economic crises in Nigeria in the 1980s. Capital flight has been steadily rising from 1998 to its peak value of $\$ 37990.8$ in 2008 , when it further nosedived in 2010.

Table 1: Capital Flight (CAPF) in Nigeria (1980-2017).

\begin{tabular}{cccc}
\hline YEAR & CAPF (\$billion) & YEAR & CAPF (\$billion) \\
\hline 1980 & 3387 & 1999 & 2170.9 \\
1981 & 10728 & 2000 & 517.6 \\
1982 & -4796.1 & 2001 & 3356.5 \\
1983 & 11569.3 & 2002 & 2723.1 \\
1984 & 1379.8 & 2003 & 13106.9 \\
1985 & 4413.7 & 2004 & 9812.1 \\
1986 & 7980.4 & 2005 & 29263.4 \\
1987 & 7945.8 & 2006 & 24307.3 \\
1988 & 2439.4 & 2007 & 26908.4 \\
1989 & 6081.4 & 2008 & 37990.8 \\
1990 & 9071.9 & 2009 & 29029.3 \\
1991 & 7660.7 & 2010 & 18454.6 \\
1992 & 8440.3 & 2011 & 23741.9 \\
1993 & 2622.5 & 2012 & 27304.2 \\
1994 & 813.5 & 2013 & 27238.2 \\
1995 & -918.9 & 2014 & 26124.7 \\
\hline
\end{tabular}




\begin{tabular}{cccc}
\hline 1996 & 1661.8 & 2015 & 26681.5 \\
1997 & -3356.8 & 2016 & 27070.7 \\
1998 & -2030 & 2017 & 27054.4 \\
\hline
\end{tabular}

Source: Author's Computation using data from WDI (2018), CBN (2018) Statistical Bulletin \& Boyce and Ndikumana (2012). We measure capital flight deploying the residual approach, since it is the most widely used technique (Aziz et al., 2014; Al-Basheer et al., 2016). Here, capital flight is computed by relating the sources of funds with the uses of funds, the former including all net official flows ( comprising of net increases in foreign debts of the public sector and the net flow of FDI) while the latter comprise additions to reserves and current account deficit. Algebraically, it is measured as: $\Delta \mathrm{EXD}+\mathrm{NFDI}-(\mathrm{CAD}+\Delta \mathrm{FER})$

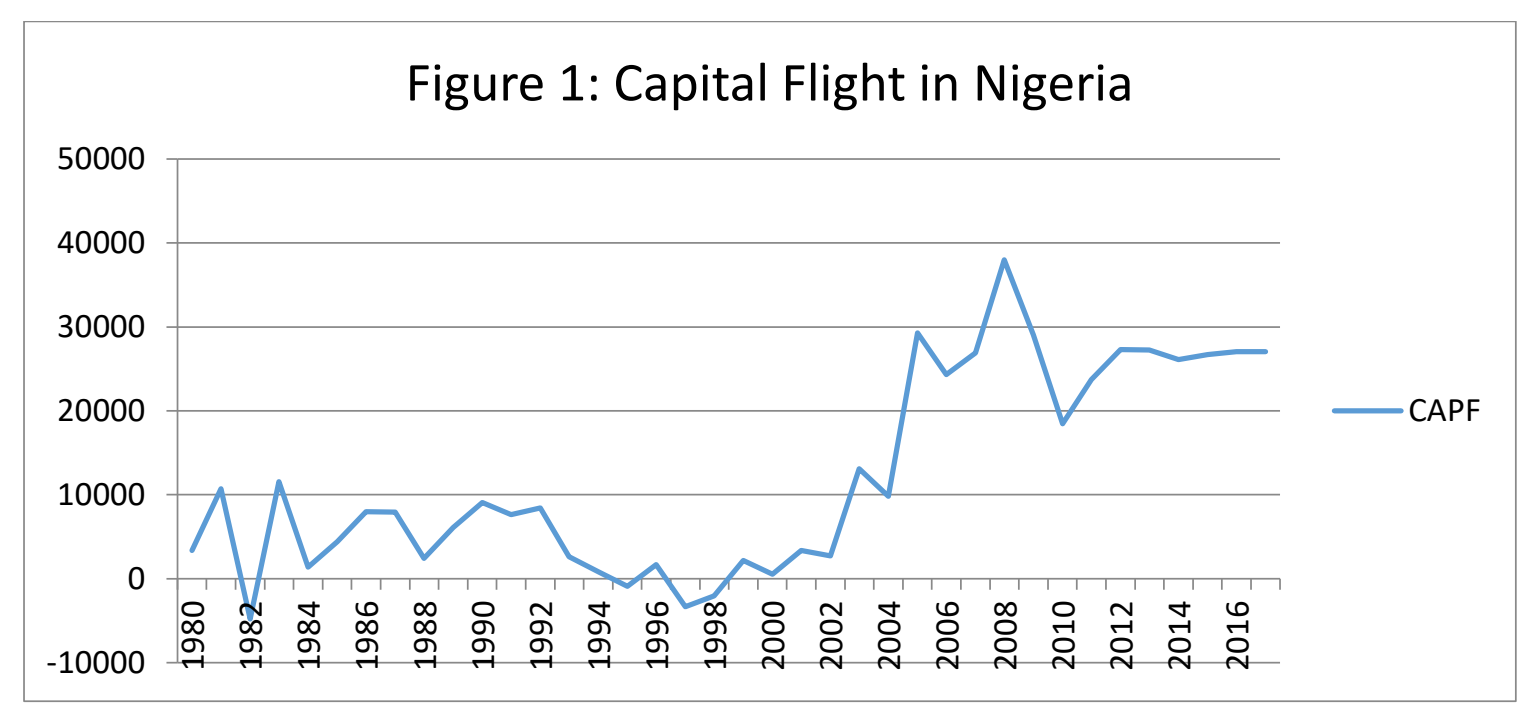

Source: Author's Computation using data from WDI (2018), CBN (2018) Statistical Bulletin \& Boyce and Ndikumana (2012)

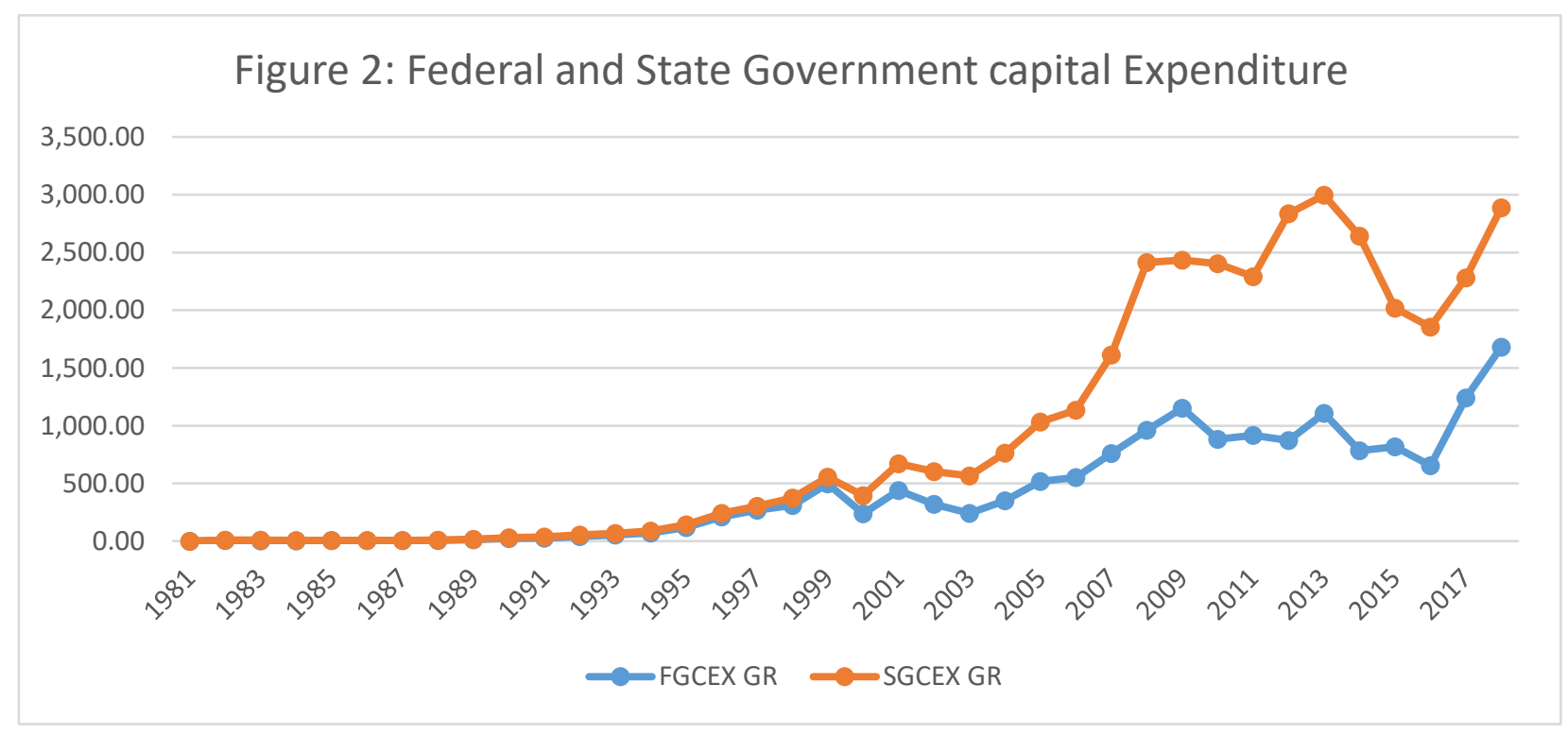

Source: Authors' Computation using data from CBN Statistical Bulletin (2018) 
Figure 2 further justifies the present effort of investigating the effects of capital flight, not just on investment spending by the central government but also incorporating capital spending by the states. From 1981, the combined capital expenditure by the subnational units were at par with that of the central government. Stable trends were also noticed up till 1999 when states' investment expenditure consistently grew above that of the Federal Government. Figure 3 exhibits the fact that notwithstanding huge public sector investment, capital flight has remained a huge challenge, competing favourably with domestic investment and exceeding the latter from 2010.

Figure 3: Capital Flight and Domestic Investment in Nigeria (1980-2017) in billions of US dollars.

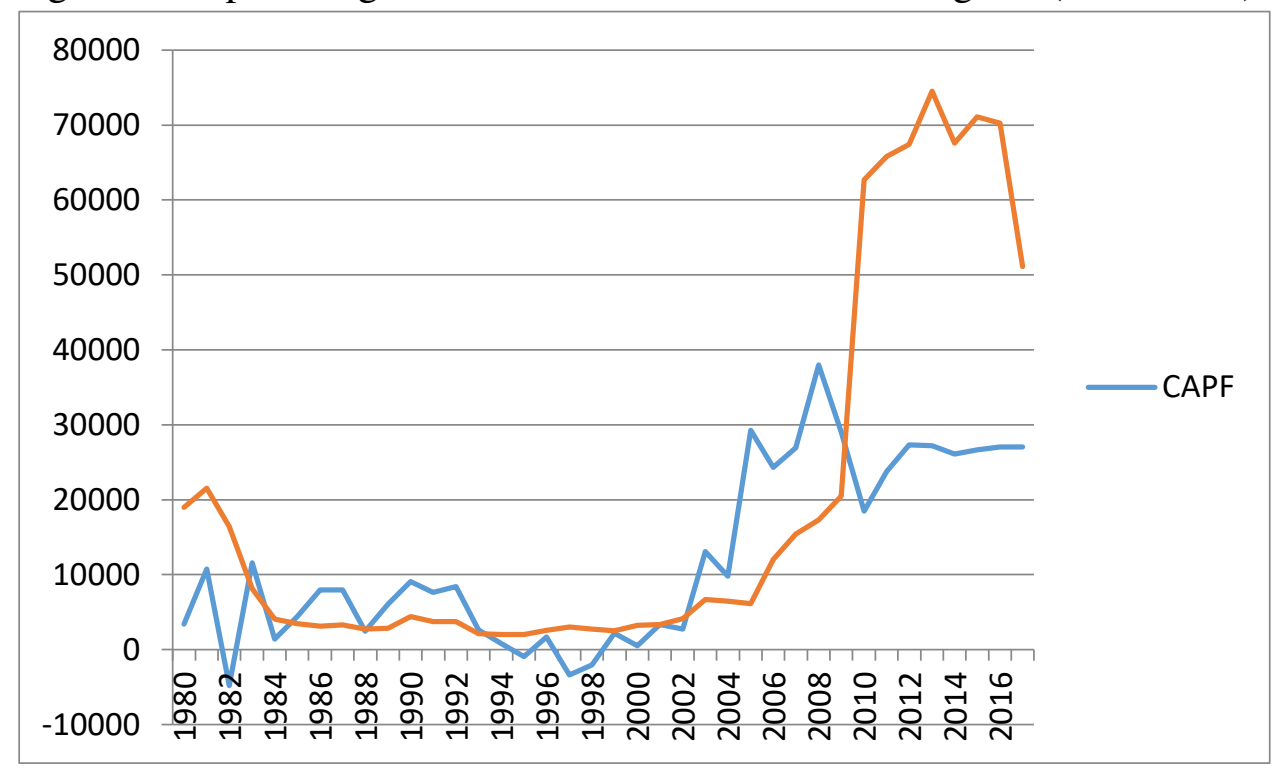

Source: Author's computation using data from CBN statistical Bulletin (2018)

\section{Research Methodology}

\subsection{The Model}

The analysis provided above on the theoretical nexus between capital flight and domestic investment justifies the adoption of an eclectic model which is a synthesis of the Keynesian theory of investment and the Investment Diversion theory of capital flight. The Keynesian theory of investment states that there is need to induce investment either by way of reduction of interest rates or by increased government expenditure. The investment diversion theory on the other hand states that macroeconomic and governmental uncertainties and presence of wide range of financial instruments abroad, cause economic agents to take away scarce resources from the domestic economy, thereby reducing investible funds and constraining domestic investment. On this score, following Ndiaye (2007), Ndikumana (2013) and Asante (2000), the functional form of the model is presented as: 
The econometric expression of equation (1) assumes the linear form:

$F G I N V=c_{0}+c_{1} C F L+c_{4} R D G P+c_{5} D B T+\mu$

The log-linear specification of equation (2) is expressed as:

$L O G(F G I N V)=c_{0}+c_{1} L O G(C F L)+c_{2} L O G(R G D P)+c_{3} L O G(D B T)+\mu \ldots \ldots \ldots$

Equation (3) is the Federal Government investment equation to be estimated. For investment by the state governments, we have the functional form presented thus:

$S G I N V=\delta_{0}+\delta_{1} C F L+\delta_{2} R D G P+\delta_{3} D B T+\mu$

The log-linear specification of equation (4) is expressed as:

$L O G\left(S G I N V_{t}\right)=\delta_{0}+\delta_{1} L O G(C F L)+\delta_{2} L O G(R G D P)+\delta_{3} L O G(D B T)+\mu$

For robustness checks, we estimate a third aggregative model to test the asymmetric effects of capital flight on total domestic investment, defined to mean the sum of federal and state government investment expenditure.

$L O G\left(T D I N V_{t}\right)=\chi_{0}+\chi_{1} L O G\left(C F L^{+}\right)+\chi_{2} L O G\left(C F L^{-}\right)+\chi_{3} L O G(R G D P)+\chi_{4} L O G(D B T)+\mu \ldots$

Where:

FGINV $=$ Federal Government investment as a ratio of the GDP

SGINV = State Government investment as a ratio of the GDP

TDINV $=$ Total domestic investment as a ratio of the GDP

CFL = Capital Flight to the GDP (residual approach estimated by World Bank 1985)

RGDP = Real Gross Domestic Product in billions of dollars

DBT $=$ Total Debt as a ratio of the GDP in billions of dollars

$\mu \quad=\quad$ Stochastic error term

$\mathrm{c}, \delta, \chi \quad=\quad$ Coefficients of economic relationship to be estimated

The above models indicate that domestic investment is impacted by capital flight, real GDP and the stock of debt. From a priori, we expect domestic investment to be a decreasing function of capital flight. Equally, real gross domestic product should exhibit a positive relationship with domestic investment. The debt stock could either accelerate or decelerate the pace of investment, depending on 
the structure of repayment and the productivity of the debt. The study employs annual secondary time series data from 1980 to 2017, sourced from the various editions of the Central Bank of Nigeria (CBN) Statistical Bulletin, the Nigerian National of Statistics (NBS) and the World Development Indicators (2018).

\subsection{Empirical Methodology}

There is a growing body of empirical studies that utilize the nonlinear autoregressive distributed lag model (NARDL) in analysing asymmetric effects and relationships in macroeconomic time series data. The NARDL is useful for several reasons. First, it permits the estimation of both dynamic and static impacts of the explanatory variables on the dependent variable. This is in contrast to a static model which only permits the estimation of fixed effects only. Second, like the conventional ARDL, it also affords the opportunity of evaluating the existence of a long-run relationship among variables, also called the bounds test. Finally, NARDL offers a framework which permits the evaluation of dynamic effects of both negative and positive changes in the regressors on a specific dependent variable (Adekunle and Ndukwe, 2018).

Suppose we specify a simple static model that expresses the relationship between domestic investment (y) and capital flight $(\mathrm{X})$ of the form:

$$
y_{t}+\beta_{t}+\beta_{1} X_{t}+\mu t
$$

Where $\beta_{1}$ is the capital flight elasticity of domestic investment, expected at a priori to be negatively signed. Equation (1) says that an increase (decrease) in capital flight leads to a contraction (rise) in domestic investment, whether private or public. Put differently, within a symmetric and linear context, the response of domestic investment to periods of capital flight surge is just a reflection of what prevails during periods of downturns in capital flight. However, to investigate the impact of the two periods concurrently, the nonlinear ARDL technique is employed (Shin et al. 2011 and 2013). In the NARDL model, nonlinearity is introduced by the decomposition of the conventional ARDL model to capture for both the long-run and short-run asymmetries in the transmission mechanism simultaneously.

According to Shin et al. (2013), the asymmetric cointegrating relationship with the NARDL framework proceeds by decomposing the exogenous variable in Equation (1) into a partial sum process represented as:

$$
y_{\mathrm{t}}=\beta^{+} X_{\mathrm{t}^{+}}+\beta^{-} X_{\mathrm{t}^{-}}+\mu \mathrm{t}
$$


Where $y_{\mathrm{t}}$ is $\mathrm{kx} 1$ vector of domestic investment at time $\mathrm{t}$; $\mathrm{X}_{\mathrm{t}}$ is a $\mathrm{k} \mathrm{x} 1$ vector of multiple regressors specified such that $X t=X_{0}+X_{\mathrm{t}}^{+}+X_{\mathrm{t}}{ }^{-}$which is the natural logarithm of capital flight; $\mu t$ represents the error term, while $\beta^{+}$and $\beta^{-}$are the corresponding asymmetric long-run parameters, showing that domestic investment responds asymmetrically during volatile or unstable periods of capital flight movement. On the other hand, $X_{\mathrm{t}}^{+}$and $X_{\mathrm{t}}{ }^{-}$signify the partial sum processes of negative (-) and positive (+) shocks in $X_{\mathrm{t}}$ defined as:

$$
\begin{aligned}
X_{t}^{+} & =\sum_{j=1}^{t} \Delta X_{j}^{+} ; X_{t}^{-}=\sum_{j=1}^{t} \Delta X_{j}^{-} \\
\Delta X_{t}^{+} & =\sum_{j=1}^{t} \max \left(\Delta X_{j}, 0\right), \Delta X_{t}^{-}=\sum_{j=1}^{t} \min \left(\Delta X_{j}, 0\right),
\end{aligned}
$$

Where $\Delta X_{j}$ represents changes in the explanatory variable $X_{\mathrm{t}, .}$ The ' + ' and the superscripts represent the negative and positive processes around a zero threshold, which defines and sets boundaries for the independent variables. This means that the series of the first difference is assumed to be normally distributed with zero mean. Equation (11) is a nonlinear ARDL (p,q) framework exhibiting both long and short run asymmetries:

$$
y_{t}=\sum_{j=1}^{p} \varphi_{j} y_{t-j}+\sum_{j=0}^{q}\left(\pi_{j}^{+1} X_{t-j}^{+}+\pi_{j}^{-1} X_{t-j}^{-}\right)+\epsilon_{t}
$$

Thus, the conditional error correction model for equation 11 with regards to the negative and positive partial sums can be expressed as:

$$
\Delta y_{t}=\rho y_{t-1}+\theta^{+} X_{t-1}^{+}+\theta^{-} X_{t-1}^{-}+\sum_{j=1}^{p-1} \varphi_{j} \Delta y_{t-j}+\sum_{j=1}^{q-1}\left(\pi_{j}^{+} X_{t-j}^{+}+\pi_{j}^{-} X_{t-j}^{-}\right)+\epsilon_{t}
$$

Shin et al. (2013) submit that equation 12 adequately corrects for the potentially feeble endogeneity of non-stationary regressors in a nonlinear ARDL model. This feature guarantees that the causal relationship proceeds from capital flight to domestic investment both in the long and short run (see for example, Coers and Sanders, 2013; Jaunky, 2011). The relationship $\beta_{t}^{+}=-\theta^{+} / \rho$ and $\beta_{t}=-\theta \% \rho$ is used in calculating the long run coefficients, while the null hypothesis of no long run relationship between the levels of $y_{\mathrm{t}}, X_{\mathrm{t}}^{+}$, and $X_{\mathrm{t}}^{-}$( which gives $\rho=\theta^{+}=\theta^{-}=0$ ) will be tested with the bound testing technique of Pesaran et al. (2001). This method is valid irrespective of the time series characteristics of $X_{t . .}$ We estimate the short and long-run asymmetries using the conventional Wald 
test. The null hypothesis of no asymmetry in the long run coefficients $\left(\beta_{\mathrm{x}}{ }^{+}=\beta_{\mathrm{x}}{ }^{-}\right)$as well as in the short-run $\left(\pi_{j}^{+}=\pi_{j}^{-}\right)$is investigated. This will result in a rejection of either or both.

Before implementing the NARDL framework, the study proceeds by undertaking preliminary test of the data to ascertain their underlying statistical as well as stationarity properties. While the former is accomplished by computing the data's descriptive properties, the latter is achieved by the use of the Augmented Dickey-Fuller (ADF) and Philip-Peron unit root tests as well as the bounds test for cointegration. We also test for the direction of causality between capital flight and domestic investment using the Granger causality test. Post-mortem or diagnostics tests were also conducted to ensure the validity and reliability of our NARDL estimates. Specifically, we test the assumptions of normality, linearity, serial correlation, and heteroskedasticity of the estimated model. Of crucial relevance to this study is the Wald test for asymmetry (both in the short-run and long-run). We test the null hypothesis that positive and negative changes in capital flight has direct opposite effects on domestic investment. The decision rule is that if the probability associated with the Wald test is greater than the conventional significance level of 0.01 or 0.05 , then the null hypothesis of no asymmetry is accepted. On the other hand, if the related probability is less than the conventional significance level, then we conclude that there is evidence of asymmetric effects of capital flight on domestic investment in Nigeria.

\section{Results and Discussion}

Table 2 presents the descriptive statistics of the data. It indicates that our core variables of interest, namely: capital flight, Federal Government investment, State Government investment and total domestic investment have mean values of 12615.57, 866.20, 19999.87, and 20866.08 respectively with corresponding maximum and minimum values as exhibited in the table. While standard deviation values show some significant drifting of the variables away from their mean values, their kurtosis however indicate that our policy variables are normally distributed. In particular, capital flight, and the different layers of investment as well as total domestic investment show kurtosis values approximately equal to 3. A few of the variables were leptokurtic, with kurtosis values exceeding 3. All variables are positively skewed, indicating a long right tail, with Jarque-Bera statistic revealing that the variables are relatively normally distributed.

In Table 3, the results of the stationarity properties of the variables are presented. It is observed that most of the variables were non-stationary at levels, except inflation. However, upon first differencing, stationarity was achieved. We thus have a situation of a mixture of variables stationary at levels and at first difference. Next, cointegration is carried out to evaluate if there is any long run cointegrating relationship amongst the variables. The bounds test is used for this purpose, and the results are 
presented in Tables 4. Cointegrating test results indicate that, though the variables are non-stationary at levels, there exist a long run relationship among them. In particular, the calculated F-statistic of 23.55, 68.56, and 8.67 for the federal government investment, state government investment and total domestic investment models were all greater than their upper bound critical values at the 5 percent level of significance. The Granger causality test result presented in Table 5 shows that there is a unidirectional causality running from capital flight to the different components of investments. This is in line with existing literature which shows that capital flight influences the quantum of resources earmarked for investment in developing countries (Ndikumana, 2000).

Table 2: Descriptive Statistics of Variables

\begin{tabular}{lcccccc}
\hline & CFL & DBT & FGINV & SGINV & RGDP & TDINV \\
\hline Mean & 12615.57 & 3250.06 & 866.20 & 19999.87 & 32253.23 & 20866.08 \\
\hline Median & 8210.35 & 1699.66 & 388.00 & 5255.25 & 22391.14 & 5955.32 \\
\hline Maximum & 37990.80 & 10948.53 & 2998.79 & 74521.40 & 69023.93 & 77520.19 \\
\hline Minimum & 517.60 & 10.10 & 6.50 & 2017.00 & 12248.80 & 2108.46 \\
\hline Std. Dev. & 11179.61 & 3497.29 & 1014.94 & 26231.77 & 19010.84 & 27088.03 \\
\hline Skewness & 0.61 & 0.95 & 0.84 & 1.28 & 0.83 & 1.27 \\
\hline Kurtosis & 2.98 & 2.74 & 2.72 & 2.86 & 2.61 & 2.84 \\
\hline Jarque-Bera & 4.34 & 5.90 & 5.72 & 10.52 & 5.39 & 10.39 \\
\hline Probability & 0.11 & 0.05 & 0.08 & 0.21 & 0.16 & 0.31 \\
\hline Sum & 479391.7 & 123502.6 & 32915.84 & 759995.2 & 1225623 & 792911.0 \\
\hline Sum Sq. Dev. & $4.62 \mathrm{E}+09$ & $4.53 \mathrm{E}+08$ & 38114426 & $2.55 \mathrm{E}+10$ & $1.34 \mathrm{E}+10$ & $2.71 \mathrm{E}+10$ \\
\hline Observations & 38 & 38 & 38 & 38 & 38 & 38 \\
\hline
\end{tabular}

Source: Authors' Computation

Table 3: Unit Roots Test Results

\begin{tabular}{lcccccccc}
\hline Variable & ADF Stats & ADF Stats & $\begin{array}{c}\mathbf{5 \%} \text { Critical } \\
\text { value }\end{array}$ & Rem & $\begin{array}{c}\text { Phillips- } \\
\text { Perron } \\
\text { Stats }\end{array}$ & $\begin{array}{c}\text { Phillips- } \\
\text { Perron } \\
\text { Stats }\end{array}$ & $\begin{array}{c}\mathbf{5 \%} \\
\text { Critical } \\
\text { value }\end{array}$ & $\begin{array}{c}\text { Rem } \\
\text { Level }\end{array}$ \\
\hline CFL & Level & $1^{\text {st }}$ Diff & Level & & Level & $1^{\text {st }}$ Diff & Level \\
\hline DBT & -2.474 & $-8.498^{*}$ & -3.536 & $\mathrm{I}(1)$ & -2.399 & $-8.631497^{*}$ & -3.540 & $\mathrm{I}(1)$ \\
\hline FGINV & -2.565 & $-3.571^{*}$ & -3.540 & $\mathrm{I}(1)$ & -1.671 & $-3.585^{* *}$ & -3.540 & $\mathrm{I}(1)$ \\
\hline SGINV & -2.206 & $-4.341^{*}$ & -3.540 & $\mathrm{I}(1)$ & -1.884 & $-4.145^{* *}$ & -3.536 & $\mathrm{I}(1)$ \\
\hline RGDP & 0.285 & $-5.192^{*}$ & -2.943 & $\mathrm{I}(1)$ & & $-5.250^{*}$ & -2.945 & $\mathrm{I}(1)$ \\
\hline TDINV & & $-3.618^{* *}$ & -3.540 & $1(1)$ & & $-3.602^{* *}$ & -3.540 & $\mathrm{I}(1)$ \\
\hline Source: & -1.474 & $-5.758^{*}$ & -3.536 & $\mathrm{I}(1)$ & -1.483 & $-5.758^{*}$ & -3.536 & $\mathrm{I}(1)$ \\
\hline
\end{tabular}

Source: Authors' Computation 
Table 4: Federal Government Investment NARDL Model Bounds Test

\begin{tabular}{|c|c|c|c|c|c|}
\hline Test Statistic & Value & K & $\begin{array}{l}\text { Lower } \\
\text { bound }\end{array}$ & $\begin{array}{l}\text { Upper } \\
\text { bound }\end{array}$ & $\begin{array}{l}\text { Sig } \\
\text { Level }\end{array}$ \\
\hline F- statistic & 23.55 & 3 & 3.62 & 4.16 & $5 \%$ \\
\hline \multicolumn{6}{|c|}{ Decision: There is co-integration } \\
\hline \multicolumn{6}{|c|}{ State Government Investment NARDL Model Bounds Test } \\
\hline Test Statistic & Value & K & $\begin{array}{l}\text { Lower } \\
\text { bound }\end{array}$ & $\begin{array}{l}\text { Upper } \\
\text { bound }\end{array}$ & $\begin{array}{l}\text { Sig } \\
\text { Level }\end{array}$ \\
\hline F- statistic & 68.56 & 3 & 2.56 & 3.49 & $5 \%$ \\
\hline \multicolumn{6}{|c|}{ Decision: There is co-integration } \\
\hline \multicolumn{6}{|c|}{ Total Domestic Investment NARDL Model Bounds Test } \\
\hline Test Statistic & Value & K & $\begin{array}{l}\text { Lower } \\
\text { bound }\end{array}$ & $\begin{array}{l}\text { Upper } \\
\text { bound }\end{array}$ & $\begin{array}{l}\text { Sig } \\
\text { Level }\end{array}$ \\
\hline F- statistic & 8.67 & 3 & 2.56 & 3.49 & $5 \%$ \\
\hline
\end{tabular}

Decision: There is co-integration

Source: Authors' Computation

Table 5: Granger causality test result

\begin{tabular}{lccc}
\hline Null Hypothesis: & Obs & F-Statistic & Prob. \\
\hline CFL does not Granger Cause FGINV & 36 & 6.88814 & 0.0216 \\
FGINV does not Granger Cause CFL & & 0.61944 & 0.5448 \\
\hline SGINV does not Granger Cause CFL & 36 & 0.37571 & 0066899 \\
CFL does not Granger Cause SGINV & & 9.37560 & 0.08007 \\
\hline \hline CFL does not Granger Cause TDINV & \multirow{2}{*}{36} & 9.40581 & 0.0006 \\
TDINV does not Granger Cause CFL & & 0.39547 & 0.6767 \\
\hline
\end{tabular}

Source: Authors' computation

\subsection{Result of Federal Government Investment - Capital Flight Model}

Table 6 presents both the short- and long-run NARDL estimated results of the optimal model $(4,3)$ obtained via the Akaike Information Criterion (AIC). Results indicate that Federal Government investment in the current period is adaptive to previous investments. In other words, current levels of investment responds positively to investments undertaken in the first, second and third lagged periods, even though it was only significant in the third lag. Capital flight for all the periods indicated negative relationship with investment. Real GDP is shown to be a significant driver of investment at the Federal level. From Panel A, we particularly note that increases (positive deviations) in capital flight [(CFL)_POS(-1))] lead to a significant reduction in investment while negative changes in capital flight [(CFL)_NEG(-1))] also significantly decreases investment undertaken at the Federal level. 
Table 6: Estimated NARDL Long run Results of the Federal Government Investment Model $(4,3)$

\begin{tabular}{|c|c|c|c|c|}
\hline \multicolumn{5}{|c|}{ Dependent Variable: LOG (FGINV) } \\
\hline \multicolumn{5}{|c|}{ Panel A - Short Run Results } \\
\hline Variable & Coefficient & Std. Error & t-Statistic & Prob. \\
\hline $\mathrm{C}$ & 4.542638 & 5.196725 & 0.874135 & 0.3930 \\
\hline DLOG(FGINV(-1)) & 0.006073 & 0.167652 & 0.036226 & 0.9715 \\
\hline DLOG(FGINV(-2)) & 0.193750 & 0.160727 & 1.205460 & 0.2428 \\
\hline DLOG(FGINV(-3)) & 0.329962 & 0.131987 & 2.499956 & 0.0217 \\
\hline DLOG(CFL_POS) & -0.065503 & 0.056263 & -1.164225 & 0.2587 \\
\hline DLOG(CFL)_POS(-1)) & -0.734328 & 0.121236 & -6.057009 & 0.0000 \\
\hline DLOG(CFL)_NEG(-1) & -0.198383 & 0.062986 & -3.149635 & 0.0040 \\
\hline DLOG(DBT)_POS(-1) & 0.220957 & 0.039778 & 5.554805 & 0.0000 \\
\hline DLOG(DBT)_NEG(-1) & -0.047196 & 0.080512 & -0.586201 & 0.5646 \\
\hline DLOG(RGDP)_POS(-1) & 0.378729 & 0.179856 & 2.105735 & 0.0474 \\
\hline DLOG(RGDP)_NEG(-1)) & -0.141556 & 0.049834 & -2.840566 & 0.0105 \\
\hline CointEq(-1) & -0.419502 & 0.145604 & -2.881108 & 0.0077 \\
\hline Adjusted R-squared & 0.648224 & & & \\
\hline F-statistic & 5.677675 & & & \\
\hline Prob(F-statistic) & 0.000297 & & & \\
\hline Durbin-Watson stat & 2.122611 & & & \\
\hline \multicolumn{5}{|c|}{ Panel B - Long run Results } \\
\hline LOG(CFL)_POS & -0.706786 & 0.138818 & -5.091464 & 0.0000 \\
\hline LOG(CFL)_NEG & -0.275903 & 0.116603 & -2.366169 & 0.0277 \\
\hline
\end{tabular}

Source: Authors' Computation

From the long run estimated results in Panel B, a 100\% increase in capital flight reduces domestic investment of the Federal Government by almost $71 \%$, while a decrease of capital flight by $100 \%$ will on the average decrease domestic investment by almost $28 \%$, all things being equal. It should be noted however that the negative effect (-0.275) of decreasing capital flight on investment is less-than the negative effects of increasing capital flight (-0.706). The short run results in Panel A apparently mimic that obtained in the long run. They indicate that an increase in capital flight [(CFL)_POS(-1))] by $100 \%$ significantly reduces domestic investment by $73 \%$. However, a reduction in capital flight [(CFL)_NEG(-1))] still depresses domestic investment, contrary to theoretical expectation. In order to ascertain the long-run symmetric or asymmetric effects of capital flight on Federal Government investment, a Wald test is conducted and results reported in Table 7 along with other diagnostic tests results.

Table 7: Test of Asymmetry of Federal Government Investment Model

\begin{tabular}{ccc}
\hline Variable & Coefficient & Prob. \\
\hline$\beta_{\mathrm{x}}{ }^{+}=\beta_{\mathrm{x}}^{-}$ & 5.12675 & 0.0064 \\
$\pi_{\mathrm{j}}{ }^{+}=\pi_{\mathrm{j}}^{-}$ & 0.56443 & 0.45321 \\
Ramsey RESET linearity test & 0.32981 & 0.34176 \\
Jarque-Bera normality test & 0.71134 & 0.31987 \\
Breusch-Godfrey serial correlation LM test & 0.66825 & 0.22552 \\
ARCH LM heteroscedasticity test & 0.87150 & 0.51074 \\
\hline
\end{tabular}


The null hypothesis of the Wald test is that there is symmetry in the positive and negative changes in capital flight on domestic investment by the Federal Government. The results indicate the presence of asymmetric effect of capital flight on domestic investment in the long run. This is because the null hypothesis of no asymmetry or symmetry in the long run coefficients $\left(\beta_{\mathrm{x}}{ }^{+}=\beta_{\mathrm{x}}{ }^{-}\right)$could not be accepted at the conventional 5 percent significance level. For the short-run $\left(\pi_{\mathrm{j}}{ }^{+}=\pi_{\mathrm{j}}{ }^{-}\right)$however, the null hypothesis of symmetric effects of capital flight must be accepted. The diagnostic results show that the model is correctly specified as indicated by the Ramsey Reset specification test, the residuals are normally distributed $(p=0.32)$, and do not suffer from autocorrelation $(p=0.23)$ and is homoscedastic $(p=0.51)$

\subsection{Results of State Government Investment - Capital Flight Model}

Table 8 presents the results of the non-linear specification of the state government investment-capital flight model.

Table 8: Estimated NARDL Long run Results of State Government Investment Model $(1,3)$ Dependent Variable: LOG (SGINV)

\begin{tabular}{lcccc}
\hline \multicolumn{1}{c}{ Variable } & Panel A - Short-run Results & & \\
\hline C & Coefficient & Std. Error & t-Statistic & Prob. \\
DLOG(SGINV(-1)) & -24.81505 & 8.572254 & -2.894811 & 0.0082 \\
DLOG (SGINV(-2)) & 0.322011 & 0.065154 & 4.942322 & 0.0001 \\
DLOG(CFL_POS) & 0.982366 & 0.132835 & 7.395390 & 0.0000 \\
DLOG(CFL_POS(-1)) & -0.738200 & 0.341240 & -2.163287 & 0.0371 \\
DLOG(CFL_NEG(-1)) & 0.198383 & 0.062986 & 3.149635 & 0.0040 \\
DLOG(DBT_POS) & 0.656253 & 0.386655 & 1.697257 & 0.1031 \\
DLOG(DBT_NEG) & -0.133827 & 0.184337 & -0.725988 & 0.4752 \\
DLOG(RGDP_POS) & 0.238590 & 0.055302 & 4.314280 & 0.0002 \\
DLOG(RGDP_NEG) & 3.092691 & 1.054470 & 2.932936 & 0.0075 \\
\hline CointEq(-1) & -0.318014 & 0.099999 & -3.180178 & 0.0037 \\
R-squared & -0.798063 & 0.200718 & -3.976048 & 0.0004 \\
Adjusted R-squared & 0.737754 & & & \\
F-statistic & 0.628485 & & & \\
Prob.(F-statistic) & 6.751718 & & & \\
Durbin-Watson stat & 0.000064 & & & \\
\hline & 2.119733 & & & \\
\hline CFL_POS & Panel B - Long-run Results & & \\
CFL_NEG & -0.370815 & 0.098997 & -3.745731 & 0.0012 \\
\hline Source:Author's Analysi & 0.158843 & 0.025511 & 6.226427 & 0.0000 \\
\hline
\end{tabular}

Source: Author's Analysis

The estimated results reveal that in the short-run, current levels of investments by State Governments are positively and significantly influenced by previous levels of investments, while real GDP significantly drives investment at the subnational level. Consistent with theoretical postulation, results show that State level investment is a decreasing function of positive variations of the debt 
stock. Specifically, an increase in the debt stock by $100 \%$ on the average results in $13.3 \%$ decrease in investment. This position was apparently controverted by the fact that the estimated parameter was non-significant, implying that investment decisions by subnational governments was not considerably influenced by the size of the existing stock of debt. Perhaps other considerations, mostly political, may have weighed in on investment decisions by States. The short-run positive variations in capital flight both at levels and in its first lag indicated an inverse and significant relationship with and impact on investment. In particular, a positive increase in capital flight by $100 \%$ is associated with about $73 \%$ decline in domestic investment. A decrease in capital flight by $100 \%$ however exerts a positive and non-significant increase in domestic investment by $65.6 \%$. While this informally suggest symmetric effects, it must be stressed that the positive effect of capital flight on domestic investment exceeds its corresponding negative impact.

Long-run estimated coefficients of capital flight indicate that a $100 \%$ increase in capital flight on the average led to $37 \%$ decrease in State Government investment, ceteris paribus, while a $100 \%$ negative deviation in capital flight led to about $15.9 \%$ increase in state level domestic investment. Table 9 presents results of the Wald test to formally ascertain the longrun symmetric effects of capital flight on State Government investment levels in Nigeria.

Table 9: Test of Asymmetry of State Government Investment Model

\begin{tabular}{ccc}
\hline Variable & Coefficient & Prob. \\
\hline$\beta_{\mathrm{x}}^{+}=\beta_{\mathrm{x}}^{-}$ & 1.52824 & 0.1414 \\
$\pi_{\mathrm{j}}{ }^{+}=\pi_{\mathrm{j}}^{-}$ & 0.03047 & 0.9760 \\
Ramsey RESET linearity test & 0.80980 & 0.95521 \\
Jarque-Bera normality test & 0.45188 & 0.98153 \\
Breusch-Godfrey serial correlation LM test & 0.43602 & 0.66625 \\
ARCH LM heteroscedasticity test & 0.39418 & 0.69647 \\
\hline
\end{tabular}

The result of the Wald test of symmetry shows that for both the long- and short-run parameters, the null hypothesis of symmetry must be accepted, since the probability values exceed the 5\% significance level. Put differently, an increase in capital flight induces a decline in domestic investment, while a corresponding decrease in capital flight leads to an increase in domestic investment. The relevant post-estimation tests reveal that the estimated model is well specified as represented by the Ramsey Reset specification test $(p=0.955)$, the residuals are normally distributed $(p=0.9815)$, and are not serially correlated $(p=0.666)$ and are homoscedastic $(p=0.696)$ 


\subsection{Results of Total Domestic Investment - Capital Flight Model}

Table 10 and its associated Table 11 are the results of the third model, which serves the purpose of robustness. It seeks to investigate if there would be any significant difference between the response of aggregate investment by both tiers of government (Federal and States) to capital flight deviations in Nigeria.

Table 10: Estimated NARDL Longrun Results of Total Domestic Investment Model (1, 0) Dependent Variable: LOG (TDINV)

$$
\text { Panel A - Short-run Results }
$$

\begin{tabular}{lcccc}
\hline \multicolumn{1}{c}{ Variable } & Coefficient & Std. Error & t-Statistic & Prob. \\
\hline \multicolumn{1}{c}{ C } & -26.28644 & 7.592621 & -3.462103 & 0.0017 \\
DLOG(TDINV(-1)) & -0.509840 & 0.109781 & -4.644175 & 0.0001 \\
DLOG(CFL_POS) & -2.822985 & 0.290040 & -9.733076 & 0.0000 \\
DLOG(CFL)_POS(-1)) & -0.733559 & 0.261911 & -2.800797 & 0.0093 \\
DLOG(CFL)_NEG(-1)) & -0.472901 & 0.178452 & -2.650022 & 0.0133 \\
DLOG(DBT_POS(-1)) & -0.935834 & 1.050526 & -0.890825 & 0.3806 \\
DLOG(DBT_NEG(-1)) & 0.307729 & 0.105011 & 2.930442 & 0.0068 \\
DLOG(RGDP_POS(-1)) & 3.344110 & 0.864301 & 3.869150 & 0.0006 \\
DLOG(RGDP_NEG(-1)) & 0.003000 & 0.002956 & 1.014984 & 0.3191 \\
\hline CointEq(-1) & -0.353342 & 0.103860 & -3.402086 & 0.0021 \\
Adjusted R-squared & 0.883012 & & & \\
F-statistic & 18.66918 & & & \\
Prob(F-statistic) & 0.00000 & & & \\
Durbin-Watson stat & 1.93005 & & & 0.0037 \\
\hline & \multicolumn{5}{c}{ Panel B - Long-Run Results } \\
LOG(CFL)_POS & -0.318014 & 0.099999 & -3.180178 & \\
LOG(CFL)_NEG & -0.220957 & 0.039778 & -5.554805 & 0000 \\
\hline Source:Author Computation
\end{tabular}

Source: Authors' Computation

Table 11: Test of Asymmetry of Total Domestic Investment Model

\begin{tabular}{ccc}
\hline Variable & Coefficient & Prob. \\
\hline$\beta_{\mathrm{x}}{ }^{+}=\beta_{\mathrm{x}}{ }^{-}$ & 2.99468 & 0.0054 \\
$\pi_{\mathrm{j}}{ }^{-}=\pi_{\mathrm{j}}^{-}$ & 2.19122 & 0.0361 \\
Ramsey RESET linearity test & 1.03666 & 0.3079 \\
Jarque-Bera normality test & 0.76477 & 0.4502 \\
Breusch-Godfrey serial correlation LM test & 0.29513 & 0.7699 \\
ARCH LM heteroscedasticity test & 0.15927 & 0.8745 \\
\hline
\end{tabular}

Results confirm that capital flight exerts similar effects on aggregate investments expenditure as it does when they are isolated. The short run results (Panel A) of the decomposition of the capital flight variable into both positive and negative deviations show that a $100 \%$ increase in capital flight, on the average, leads to $73.3 \%$ decrease in total domestic investment in Nigeria. A reduction in capital flight 
which was theoretically expected to exert a positive impact on total domestic investment, turned out with a contrary result. Specifically, it is associated with a $47.2 \%$ decline in total domestic investment, suggesting, by the rule of thumb, a short-run asymmetric impact. The non-linear long-run decomposition of the positive and negative deviations indicate that positive deviations in capital flight by $100 \%$ impacts negatively on domestic investment by about $31.8 \%$. A surge in capital flight causes significant reductions in domestic investment, which aligns with theoretical postulations. However, when capital flight declines by the same amount, domestic investment reduces by $22 \%$. Paradoxically, declining trend in capital flight did not translate to increases in domestic investment. This contradicts theoretical expectations, thereby, connoting asymmetric relationship.

Table 11 presents the results of the Wald test of symmetry to determine conclusively the relationship existing between these deviations. With a probability value of less than $5 \%$, the null hypothesis of symmetry between the effects of negative and positive deviations of capital flight on total domestic investment in Nigeria must be refuted. In effect, we conclude that there exist asymmetric effects of capital flight on public sector investment in Nigeria in both short- and longrun. The post-estimation tests are all satisfactory.

Our findings broadly agree with empirical evidence furnished from previous studies showing that capital flight hurts economic growth of victim economies (Akinwale, 2020; Anetor, 2019; Ndikumana, 2016). Capital flight impacts growth through its direct effect on investments. On this score, our results are in tandem with that of Ndikumana and Boyce (2018) and The World Bank (2015) who aver that capital flight in Nigeria has been a significant constraint on investment. The study's findings are at variance with Rahmon (2017). Regrettably, however, we could not find a study to either compare or contrast the findings of this paper with specific regards to the question of asymmetric effects of capital flight on investments, which was the major thrust of our inquiry.

\section{Conclusion and Recommendation}

This study employs the NARDL to test the existence or otherwise of symmetry in the response of public sector investment (States and Federal Governments) to capital flight in Nigeria. Our findings indicate that over the long term, there exist asymmetric effect of capital flight on Federal Government investment in Nigeria. This means that an increase in capital flight induces a reduction in the investment capacity at the Federal level, while a corresponding reduction in capital flight does not lead to an increase in investment. Investment by subnational governments however revealed the existence of symmetry in both the short and long run, while overall, total public sector investments (by both States and Federal Governments) indicated once again the prevalence of asymmetric effects 
between positive and negative deviations of capital flight. For investments by the States, a surge in capital flight induced a reduction in investment, while its corresponding decline initiated a rise in investment.

Several factors could be adduced for this outcome, one of which could be that persistence of capital flight may worsen the fiscal position of the government, inducing external borrowing, with consequences on repayment of both principal and interest. Ndiaye (2014) is particularly worried with the consequences of debt unsustainability in the presence of capital flight, while Ajayi (1997) laments that external borrowing and the availability of foreign exchange actually fuel its persistence Thus, even when there is a significant reduction in capital flight, government may have to grapple with the short to medium term negative effects of its occurrence. In the meantime, investment must be halted or considerably slowed. Furthermore, the negative macroeconomic distortions of capital flight especially on inflation and exchange rate stability might account for this asymmetry, considering the implications of capital flight on the value of government receipts, which form the basis its investments outlay. Our findings have implications for the range of policy alternatives available to government to curb the menace of capital flight. Traditional policy tools to control capital flight and boost investment, for instance, may rest on the erroneous assumption that once capital flight is significantly curbed, domestic investment may surge almost immediately by default. But this might not be the case, with the present evidence furnished of asymmetric effects of capital flight on investment behaviour. This means that besides conventional policy tools, for example, of strengthening institutions, government must think out of the box in dealing with problems of asymmetric impacts of capital flight and investment behaviour, in both the short to the long term.

\section{Declarations}

\section{Acknowledgments}

We sincerely thank the prospective reviewers and editors of this paper, because their inputs will undoubtedly help improve the quality of the manuscript.

\section{Authors' Contributions}

The First Author (LE) conceptualised the study, wrote the introduction through to the literature review, the second author (EU) handled the methodology and results section, while OAO and FAE sourced for data, and also did some parts of the analysis. All authors proofread and approved the submission of the manuscript

\section{Funding}

There is no funding whatsoever for this study

\section{Availability of data and materials}


Data for this study are sourced from the Central Bank of Nigeria Statistical Bulletin as well as the World Bank Development Indicators

\section{Competing Interests}

I hereby declare that there are no present or potential competing interests for this study 


\section{References}

Adekunle, W. \& Ndukwe, I. (2018). The impact of exchange rate dynamics on agricultural output performance in Nigeria. MPRA Paper No. 87755. Online at https://mpra.ub.unimuenchen.de/87755/

Adetiloye, K. A. (2012). Capital flight versus domestic investment in developing countries: An empirical analysis from Nigeria. International Journal of Economics and Finance 4(2), 175 186

Ajayi, S. I. (1997). An analysis of external debt and capital flight in the severely indebted low income countries in Sub-Saharan Africa. Research Department, International Monetary Fund Working Paper 68 (Washington DC).

Akinwale, S.O. (2020). Capital flight and economic development: Evidence from Nigeria. Management and Economics Research Journal, 10(2), pp. 1 - 10

Al-basheer, A.B., Al-Fawwaz, T.M. \& Alawneh, A.M. (2016). Economic determinants of capital flight in Jordan: An empirical study. European Scientific Journal, 12(4): 322-334.

Anetor, F.O. (2019). Macroeconomic determinants of capital flight: Evidence from the Sub-Saharan African countries. International Journal of Management, Economics and Social Sciences, Vol. $8(1), 40-57$.

Asongu, S. A. \& Nnanna, J. (2020): Governance and the capital flight trap in Africa, Transnational Corporations Review, DOI: 10.1080/19186444.2020.1771123

Asongu, S.A. \& Odhiambo N. M. (2019). Governance, capital flight and industrialisation in Africa. Journal of Economic Structures 8(36) https://doi.org/10.1186/s40008-019-0170-2

Aziz, M.S.I., Khayyam, M.O. \& Uddin, M.M. (2014). Determinants of capital flight in Bangladesh: an econometric estimation. Developing Country Studies, 4(25): 121-134.

CBN Statistical $\quad$ Bulletin. $\quad$ (2018). $\quad$ Retrieved from http://www.cenbank.org/OUT/PUBLICATIONS/STATBULLETIN/RD/2010/STABULL2018.PDF

Chipalkatti, N. and Rishi, M. (2001). External debt and capital flight in the Indian economy. Oxford Development Studies, 29, 31-44. https://doi.org/10.1080/13600810124596

Coers, R. and Sanders, M. (2013). The energy-GDP nexus: Addressing an old question with new methods. Energy Economics, 36, 708-715

Collier P., A. Hoeffler and C. Pattillo (2004). Aid and capital flight. Oxford University: Centre for the Study of African Economies.

Collier, P., Hoeffler, A., Pattilo, C., (2001) Flight capital as a portfolio choice. The World Bank Economic Review 15(1) 15e80

Cuddington, J.T.(1987). Capital Flight: Estimates, issues, and explanations. Princeton Studies in International Finance, Princeton University, p. 58.

Deppler, M. \& Williamson, M. (1987). Capital flight: Concepts, measurement and issues. Staff Papers for the World Economic Outlook. Washington, DC. International Monetary Fund.

Demir, F. (2004). A failure story: Politics and financial liberalization in Turkey, Revisiting the revolving door hypothesis. World Development, 32(5), 851-869.

Effiom, L. and Edet, S. E. (2019). Facilitation of foreign direct investment: Evidence from Cross River State, Nigeria. International Journal of Accounting \& Finance 8 (2), 78-98

Englama, A., Oputa, N. C., Ogunleye, T. S., \& Omotosho, B. S. (2007). Capital flight from Nigeria: An empirical estimate. Central Bank of Nigeria Economic and Financial Review, Vol. 45(3).

Forson, R., Obeng, K.C. \& Brafu-Insaidoo, W. (2017). Determinants of capital flight in Ghana. Journal of Business and Enterprises Development, 7, 151-180

Gankou J-M, Bendoma M, Sow MN (2016) The institutional environment and the link between capital flows and capital flight in Cameroon. African Development Review 28(S1):65-87 
Hermes, N. and Lensink, R. (2000). Capital flight and the uncertainty of government policies. University of Groningen.

Jaunky, V. C. (2011). The CO2 emissions-income nexus: Evidence from rich countries. Energy Policy, 39, 1228-1240.

Le, Quan V. and Rishi, M. (2005). Corruption and capital flight: An empirical assessment.

International Economic Journal, 20(4), 523-540, DOI: 10.1080/10168730601027161

Le and Zak (2006). Corruption and capital flight: an empirical assessment. International Economic Journal. Vol. 20(1) pp. 532-540

Lerner, J and Tufano, P. (2011). The consequences of financial innovation: A counterfactual research agenda. Annual Review of Financial Economics. DOI: 10.1146/annurev.financial.050808.114326

Lessard, D. R. and Williamson, J. (1987). Capital flight and Third World debt, Institute of International Economics, Washington DC,

Ndiaye, A. S. (2009). Effect of capital flight on domestic investment in the franc zone. African Econometric Society. $14^{\text {th }}$ Annual Conference on Econometric Modeling for Africa, Sheraton hotel, Abuja, Nigeria, 8-10 July 2009.

Ndiaye, A. S. (2014). The role of capital flight in the fluctuations in domestic investment: Evidence from African Countries in the Franc Zone. Centre for the Studies of African Economies. Conference on Economic Development in Africa, St. Catherine's College, Oxford, United Kingdom.

Ndiaye, A. S., (2007). Examining the effect of capital flight on domestic investment in the franc zone. Paper prepared for presentation at the African Econometric Society (AES) 14th Annual Conference on Econometric

Ndikumana, L. and Boyce, J.K. (2018). Capital flight from Africa: Updated methodology and new estimates. Political Economy Research Institute (PERI) Report. University of MassachusettsAmherst

Ndikumana, L. (2013). Capital flight and tax havens: impact on investment and growth in Africa. Department of Economics and Political Economy Research Institute, University of Massachusetts at Amherst.

Ndikumana, L. (2014). Capital flight and tax havens: Impact on investment and growth in Africa. HS02 Vol. 22 | pages $99-124$

Ndikumana, L. (2016). Causes and effects of capital flight from Africa: Lessons from case studies. African Development Review 28(S1):2-7

Nyatepe-coo, A.A. (1994). Capital flight in low-income sub-Saharan Africa. The effects of political climate and macroeconomic policies. Scandinavian Journal of Development Alternatives, $\mathrm{pp}$ $59-68$

Nyoni, T. (2000). Capital flight from Tanzania. In Ajayi, I. and M.S. Khan (eds).External debt and capital flight in Sub-Sahara Africa. Washington, D.C.: The IMF Institute, pp 265-299.

Okoli, M. N. \& Akujuobi, A. B. C. (2009). Determinations of capital flight: The case of Nigeria. International Journal of Development and Management Review. Vol. 4 (1), 233-246

Olopoenia, M. (2000). Capital flight from Tanzania. In Ajayi, S .I. and M.S. Khan (eds) External debt and capital flight in Sub-Sahara Africa. Washington, D.C.: The IMF Institute, pp 238264.

Olowofeso, O. E., Adeboye, A. A., Adejo, V.T., Bassey, K. J. and Abraham, O. (2017). Agricultural sector credit and output relationship in Nigeria: Evidence from nonlinear ARDL. CBN Journal of Applied Statistics Vol. 8(1), 101-122

Onwioduokit, E.A. (2000). Capital flight from Nigeria: an empirical examination. West African Monetary Institute, Accra, Ghana.

Pastor, Manuel, Jr (1990). Capital flight from Latin America, World Development 18:1-18.

Pesaran, M.H., Shin, Y. and Smith, R.J. (2001). Bounds testing approaches to the analysis of level relationships. Journal of Applied Econometrics, 16 (3), 289-326. 
Rahmon, A. B. (2017). An empirical investigation of capital flight and domestic investment in Nigeria (1980-2015). Journal of Economics and Sustainable Development, 8(24), 8-16

Salandy, M., and Henry, L. (2013). The impact of capital flight on investment and growth in Trinidad and Tobago, 1971-2008.https://pdfs.semanticscholar.org

Samson, O. and Edeme, R. (2012). Capital flight and Nigeria's economy. JORIND 10 (2), 304-320

Shin, Y. and Yu, B. and Greenwood-Nimmo, M. (2013). Modelling asymmetric cointegration and dynamic multipliers in a nonlinear ARDL framework. Festschrift in Honor of Peter Schmidt, W.C. Horrace and R.C. Sickles, eds., Forthcoming. Available at SSRN: https://ssrn.com/abstract=1807745or http://dx.doi.org/10.2139/ssrn.1807745

Tornell, A. and Velasco, A. (1992). The tragedy of the commons and economic growth: Why does capital flow from poor to rich countries? Journal of Political Economy, 100(6), 1208-31.

Uguru, L.C. (2016).On The Tax Implications of Capital Flight: Evidence from Nigeria.

Umoru, D. (2013). Capital flight and the Nigerian economy. European Journal of Business and Management Vol.5 (4). 40 - 50

Usman, F. R. and Arene, C. J. (2014). Effects of capital flight and its macroeconomic determinants on agricultural growth in Nigeria. International Journal of Food and Agricultural Economics $2(4), 1-20$.

World Bank (1985). World development report 1985. Washington, D.C.: World Bank.

World Bank (2015). World development indicators 2015. Washington, D.C.: World Bank. 
Figures

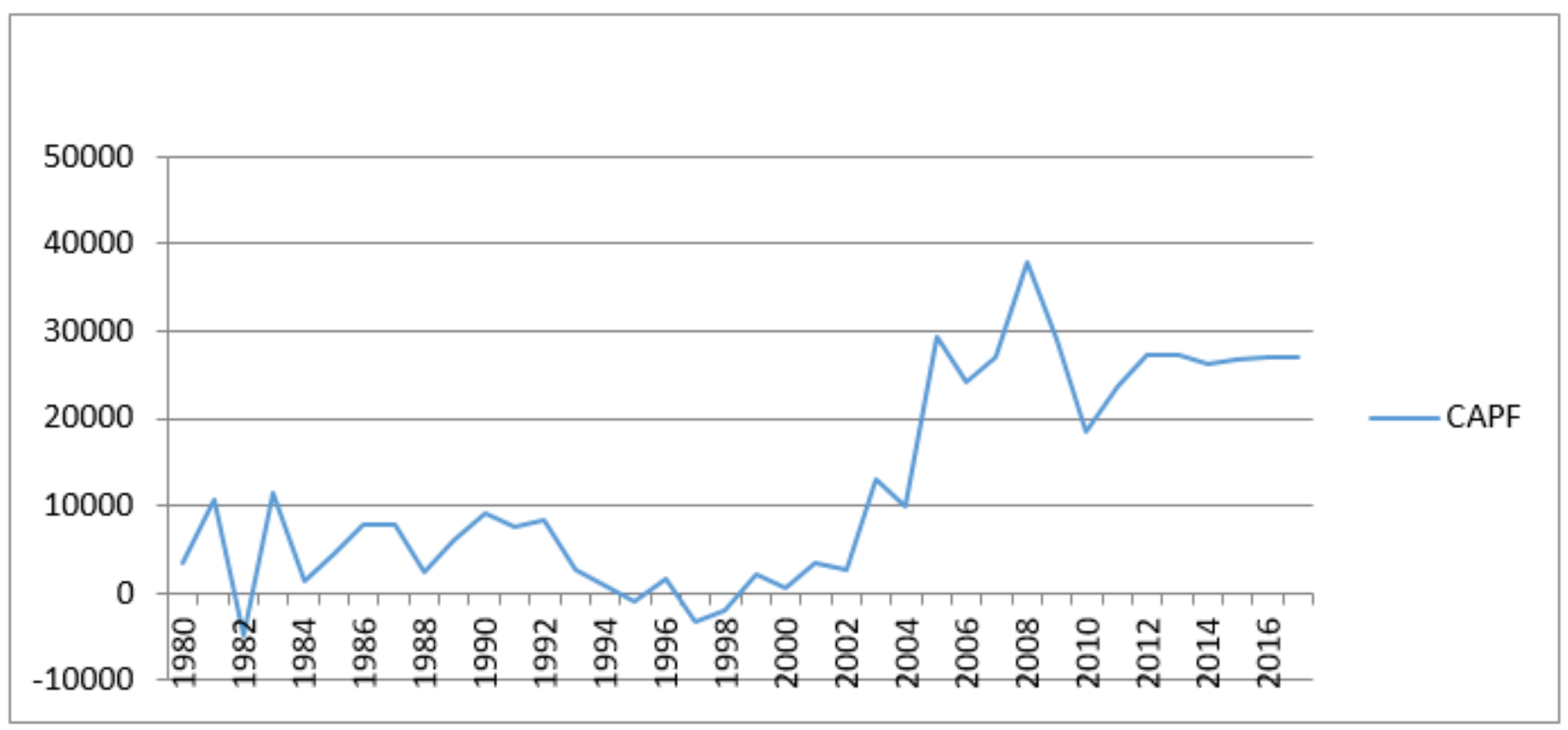

\section{Figure 1}

Capital Flight in Nigeria Source: Author's Computation using data from WDI (2018), CBN (2018) Statistical Bulletin \& Boyce and Ndikumana (2012)

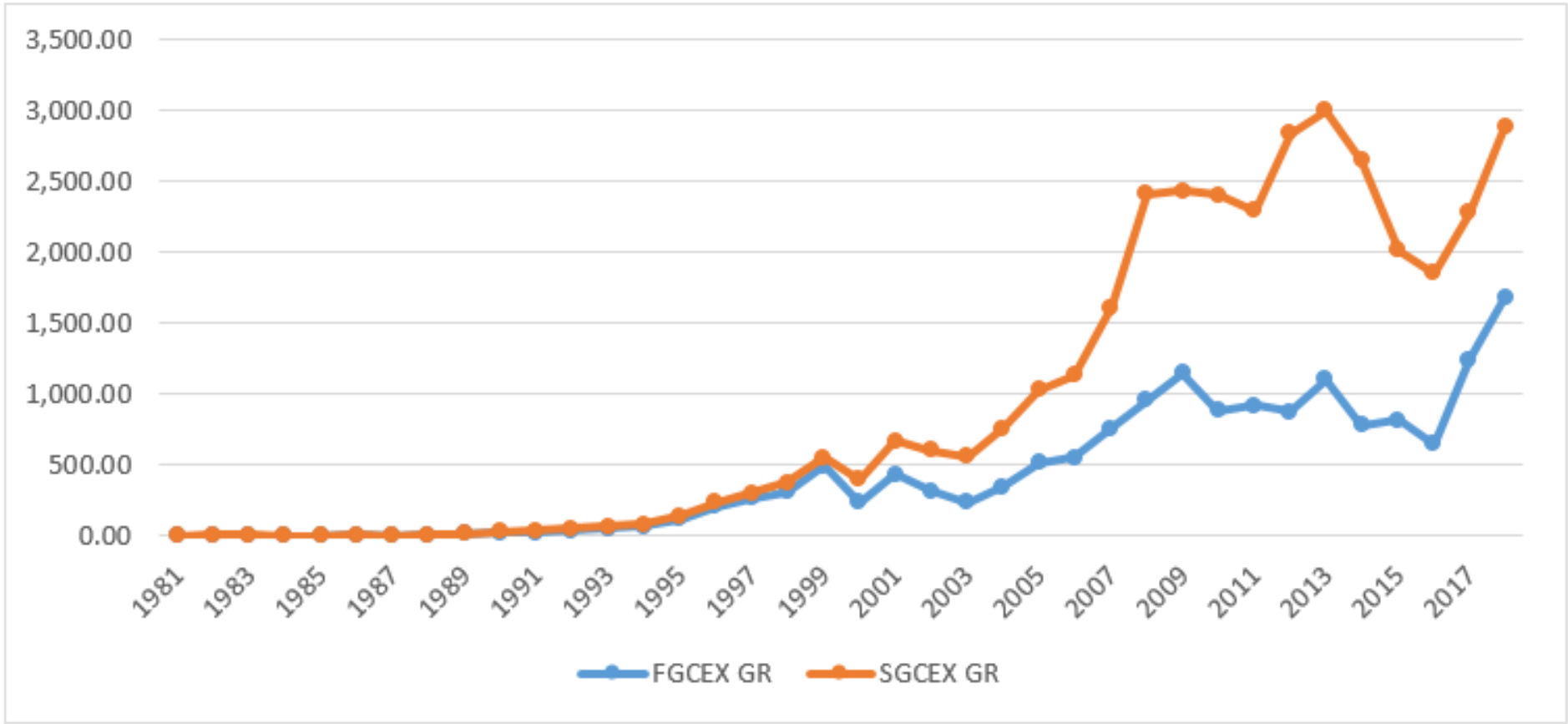

\section{Figure 2}

Federal and State Government capital Expenditure Source: Authors' Computation using data from CBN Statistical Bulletin (2018) 


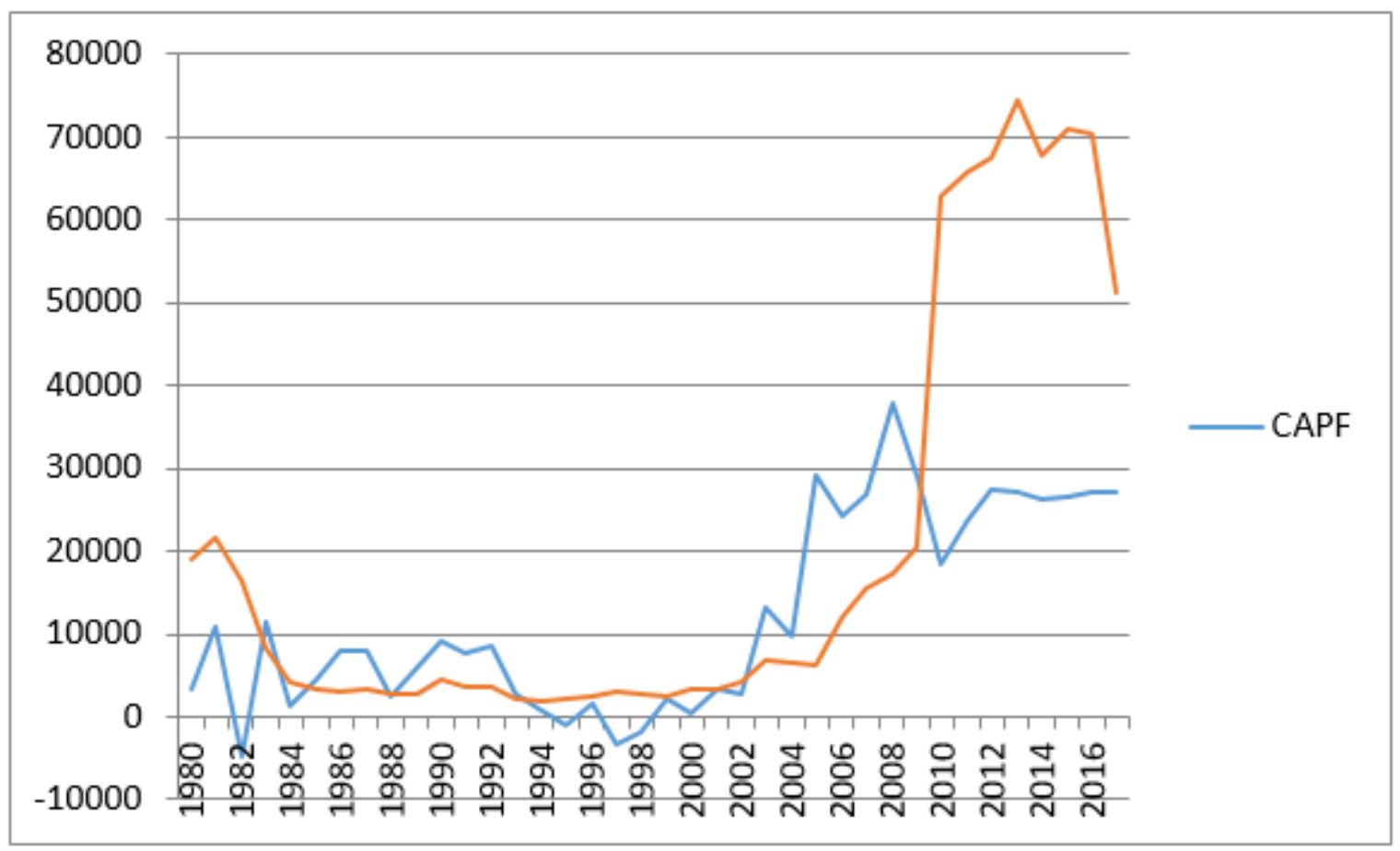

Figure 3

Capital Flight and Domestic Investment in Nigeria (1980-2017) in billions of US dollars. Source: Author's computation using data from CBN statistical Bulletin (2018) 